\title{
Significance of downregulation of renal organic cation transporter (SLC47AI) in cisplatin-induced proximal tubular injury [Corrigendum]
}

Mizuno T, Sato W, Ishikawa K, et al. Onco Targets Ther.

2015;8:1701-1706.

On page 1703, Figure 1, the y-axis label for parts A and $\mathbf{B}$ should have read "Fold change (MATE/SLC47A1 mRNA/GAPDH mRNA)" rather than "Fold change (TG2 mRNA/GAPDH mRNA)". "TG2, transglutaminase 2" also should be removed from the abbreviations list.

\section{Publish your work in this journal}

OncoTargets and Therapy is an international, peer-reviewed, open access journal focusing on the pathological basis of all cancers, potential targets for therapy and treatment protocols employed to improve the management of cancer patients. The journal also focuses on the impact of management programs and new therapeutic agents and protocols on patient perspectives such as quality of life, adherence and satisfaction. The manuscript management system is completely online and includes a very quick and fair peer-review system, which is all easy to use. Visit http://www.dovepress.com/testimonials.php to read real quotes from published authors. 